\title{
Granulomatous Mastitis, Radio-Histological Correlation
}

\author{
Priscila Falla Berganza, Mariela Sosa Ramos \\ Master's Degree in Radiology and Diagnostic Imaging, San Carlos University, Guatemala City, Guatemala \\ Email: pris.falla@gmail.com, sosa6ramosm@gmail.com
}

How to cite this paper: Berganza, P.F. and Ramos, M.S. (2020) Granulomatous Mastitis, Radio-Histological Correlation. Open Journal of Radiology, 10, 223-229. https://doi.org/10.4236/ojrad.2020.104022

Received: December 8, 2020

Accepted: December 25, 2020

Published: December 28, 2020

Copyright (c) 2020 by author(s) and Scientific Research Publishing Inc. This work is licensed under the Creative Commons Attribution International License (CC BY 4.0).

http://creativecommons.org/licenses/by/4.0/

(c) (i) Open Access

\begin{abstract}
Granulomatous mastitis, also called granulomatous lobular mastitis, is a benign pathology of the mammary gland characterized by chronic inflammation of the gland tissue, which becomes erythematous, manifesting itself as a palpable and painful mass on physical examination, sometimes it can be accompanied by abscesses. The following case is a 45 -year-old Guatemalan female, with a history of increased volume in the left breast, compromising the upper quadrants. A mammogram was performed, followed by breast ultrasound; the diagnosis was confirmed by histology. The treatment offered was surgery with image controls every six months.
\end{abstract}

\section{Keywords}

Breast Density, BIRADS, Mastitis, Granulomatous Mastitis, Biopsy, Histological, Mammography, Echography

\section{Introduction}

Granulomatous mastitis is a disease characterized by chronic inflammation of the mammary gland that occurs most of the time with erythema causing palpation of the painful mass [1]. This pathology is considered idiopathic, although there are many theories about its origin [1]. The autoimmunity theory is the main factor; however, it is thought to be secondary to an unknown pathogen or an extravasation reaction of a secretion at the zone of the breast lobules or as a consequence of gram-positive bacteria in several patients diagnosed with granulomatous mastitis [1] [2]. It generally occurs in women of reproductive age without race distinction, with a history of breastfeeding [2]. Imaging tests such as mammography and ultrasound are not definitive for the diagnosis; this is done through a biopsy [3] [4]. As for the treatment, it can be varied, it responds well to steroids, but in certain patients, this pathology can have recurrences [4]. 
We present the case of a patient who developed granulomatous mastitis in breastfeeding, because it's a challenge for the diagnosis and treatment, in addition to leading controversy for the medical group.

\section{Case Report}

A 45-year-old woman, from Sololá, Guatemala, without a previous pathological history, starting 4 months ago with increased in volume in the left breast, predominantly the upper quadrants, with an induration zone, accompanied by pain on palpation without retraction of the nipple or clinical signs of abscess formation. The patient give birth her baby 2 years ago, she gave breastfeeding around 14 months, and then decided to suspend breastfeeding and start with respective medical management (antibiotics) is sent to perform imaging studies for diagnosis decision-making regarding treatment. Her physician referred her to perform a mammography (Figure 1, Figure 2). It was reported as breast density ACR D, BIRADS 0, with a hyperdense image of poorly defined margins and trabecular thickening, located in the intercuadrant zone of the left breast; the dimensions of the lesion are $7.8 \times 4.4 \times 4.8 \mathrm{cms}$. She was called for our diagnostic department to assess breast echography (Figure 3); ultrasound findings of the left breast show a skin thickening, with edema of soft tissue and of fibroglandular tissue. She came a month later with a histological result of a biopsy performed on the left breast (Figure 4), which reported extensive inflammatory lymphoplasmacytic infiltrate in the breast tissue. These infiltrates constituted by abundant plasma cells associated with small lymphocytes that have little cytoplasm and basophilic nuclei; without atypia or mitosis figures, areas of edema and hemorrhage are also seen. In other areas, occasional giant foreign body type cells are associated with some epithelioid histiocytes that do not identify malignant cells in the examined tissue. Diagnosis: granulomatous mastitis of plasma cells

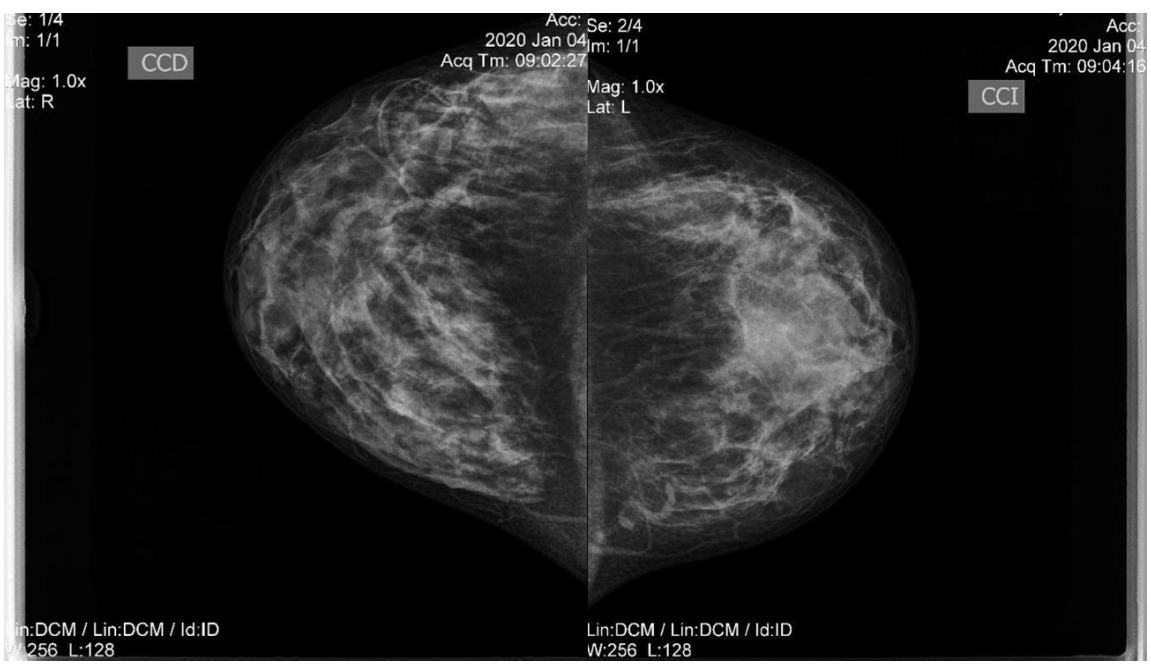

(a)

(b)

Figure 1. Image craniocaudal view. (a) Right breast view of the normal tissue; (b) The left breast shows poorly defined and thickening of the breast tissue. 


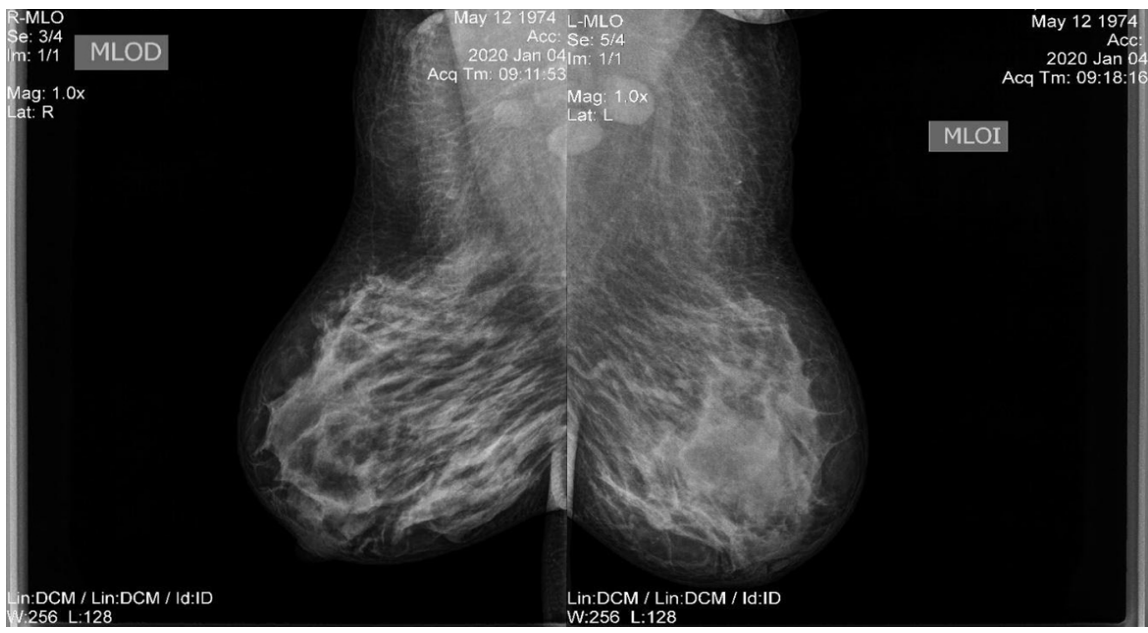

(a)

(b)

Figure 2. Mediolateral oblique view: (a) Right breast tissue without any alterations. (b) Shows poorly defined and high-density breast tissue.

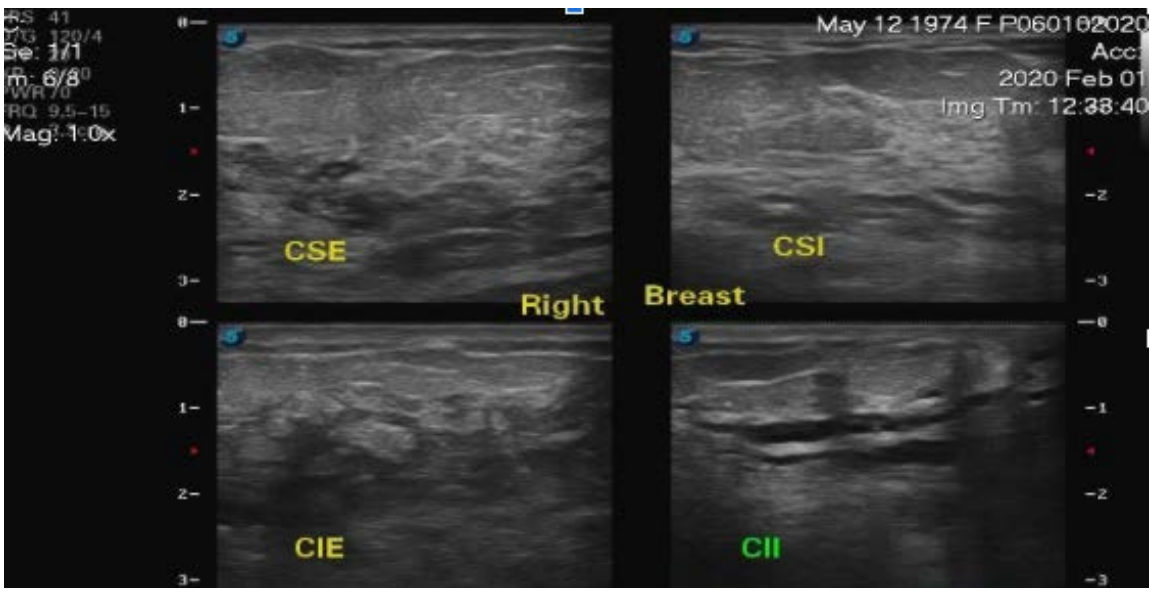

Figure 3. Ultrasound findings of the left breast shown a skin thickening, with Edema of soft tissue and fibroglandular tissue.

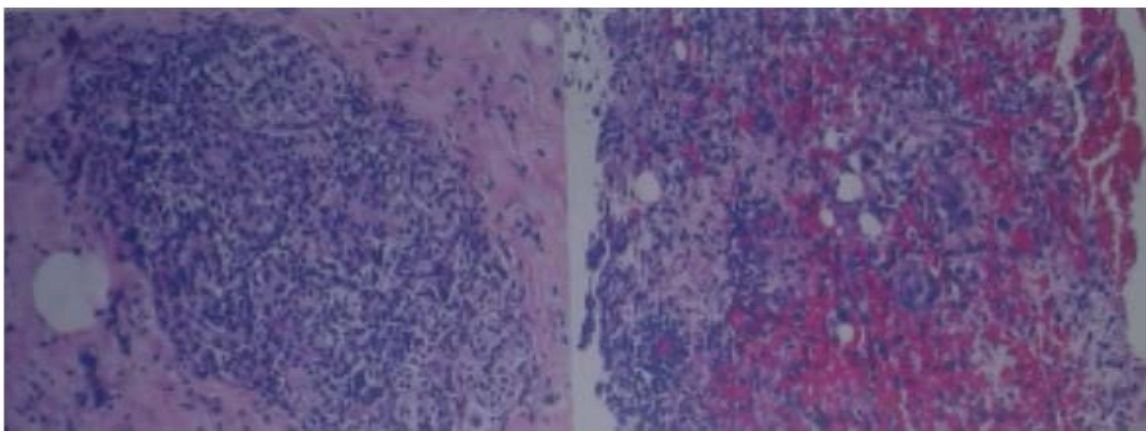

(a)

(b)

Figure 4. The histopathological study showed: (a) Extensive inflammatory lymphoplasmacytic infiltrate in the breast tissue. These infiltrates constituted by abundant plasma cells associated with small lymphocytes with little cytoplasm and basophilic nuclei; without atypia or mitosis figures, areas of edema and hemorrhage are also seen. (b) In other areas, occasional giant foreign body type cells are associated with some epithelioid histiocytes that do not identify malignant cells in the examined tissue. 
without evidence of malignant cells. "Chronic Granulomatous mastitis.", the patient avoids any treatment, due she was programed to mastectomy but never felt, comfortable and agree, in the follow of the case the patient its stable and ask her to come each 6 month without any cost of mammography and breast ultrasound.

\section{Discussion}

Granulomatous mastitis is considered difficult to diagnose lesions that are usually confused with malignant processes [1]. Described for the first time in 1972-1974 by Kessler and Wolloch, since their description, they do not exceed 500 cases without there being some consensus with the scientific community about this disease [1] [2]. It is a benign disease of the mammary gland, of unknown origin; it is believed to be associated with autoimmune reactions, erythema nodosum, polyarteritis, infections, especially those related to gram-positive bacteria such as corynebacterium and even prolonged use of oral contraceptives [3] [4].

Granulomatous mastitis primarily affects women of reproductive age between 17 - 42 years, with an average of 34 years; in recent studies, an incidence of 2.4 cases per 100,000 women in the United States has been observed, predominantly in Hispanic women [5]. Sometimes this disease is associated with pregnancy and lactation. The most frequent clinical finding is a palpable, unilateral mass, sometimes pain associated with inflammatory changes, abscesses, and fistulas [6] [7]. Due to these characteristics, they are often considered malignant processes, confusing clinicians, and radiologists with little experience, which leads them to take erroneous behaviors until the performance of unnecessary mastectomies [7].

The radiological findings are nonspecific that can simulate malignancy; in most mammographic reports, they are described as an asymmetric, poorly defined increased density. In the ultrasound, an irregular, hypoechogenic image of a tubular or nodular shape takes the appearance of a large mass [8]. Some experts suggest that a trucut biopsy is necessary for a safe diagnosis, showing greater sensitivity than a fine needle biopsy; another option is an open biopsy [9] [10]. Histologically it is an inflammatory process focused on mammary lobules containing polymorphonuclear leukocytes, plasma cells, and giant Langhans-like cells that involve the mammary gland [11] [12].

Although the definitive diagnosis is histological, radiological images are considered necessary to assess the extension, response to treatment, and follow-up cases [12].

Differential diagnoses are diverse; epidemiology must be taken into account due to those associated with infections, including tuberculous mastitis, ductal ectasia, diabetic mastopathy, sarcoidosis, and fat necrosis, and breast carcinoma, the most feared [13].

The adequate treatment has not been established and remains controversial. Treatment options that have been tried include observation, steroids, antibiotics, 
immunosuppressive agents, and surgery. Observation is used in patients with initial episodes, based on conservative management studies with successful results [14].

Oral corticosteroids have been used to treat granulomatous mastitis with successful results, with the only drawback being their associated adverse effects [14] [15]. There is no established management protocol, so it is left to each doctor [15]. Initially, high doses of prednisone are used at doses between $60-120 \mathrm{mg}$ every day for three to six months with a decrease in these to avoid reactions, although in some cases of relapse and when they do not respond to steroids, methotrexate in weekly doses can be used [16]. Lastly, surgery, which has obtained different results, has been considered the treatment of choice with strict surveillance because it is associated with recurrences and fistulas' appearance; however, surgical excision has relapsed due to the excellent response steroids and due to high rates of poor healing. In some extreme situations that treat steroids, methotrexate, or cosmetic sequelae, a mastectomy with reconstruction may be considered [17].

The criterion that some authors consider that surgery plays an important role only for the drainage of some complicated abscess and as a means to obtain a better sample for histopathological study in situations where the diagnosis is not conclusive [17].

The use of antibiotics is controversial because it will depend on the available microbiological data, many of which are directed at gram-positive agents [17] [18]. They can also be used in conjunction with incision and drainage, specifically where abscesses form [18].

In our case, the treatment chosen was surgery and follow-up every six months employing imaging studies.

\section{Conclusions}

In granulomatous mastitis, the definitive histopathological diagnosis is reported infrequently. Its broad clinical spectrum is a benign condition commonly present in women of reproductive age and imaging findings are nonspecific, which generates a diagnostic and therapeutic dilemma.

Differential diagnoses must always be taken into consideration for an accurate diagnosis that leads to a safe assessment. The first-line treatment is steroids, which has seen its good response in many patients; however, when it fails, the second option is methotrexate.

Regarding surgery, some studies may be a recurrence factor of the disease, but mastectomy and breast reconstruction can be performed in case the medications, as mentioned above, don't work.

\section{Authors' Contribution}

Both authors have read and approved the final manuscript to be submitted for publication. 


\section{Consent}

Both authors have received written, informed consent from the patient.

\section{Conflicts of Interest}

The authors declare no conflicts of interest regarding the publication of this paper.

\section{References}

[1] Anguiano-Yazbek, R. and Ávila-Toscano, A. (2016) Mastitis granulomatosa: Un reto para el diagnóstico. Cirugía Plástica, 26, 82-87. https://www.medigraphic.com/pdfs/cplast/cp-2016/cp162e.pdf

[2] Mariscal Martínez, A., Durany Lara, D., Vizcaya Martín, S., Arce Gil, J., Sanchez Torres, M.C. and Quintero Rivera, J.C. (2012) Mastitis granulomatosa. Hallazgos mamográficos, ecográficos y por RM; con correlación anatomo-patológica. Sociedad Española de Radiología Médica. Poster S-1571, 1-17.

[3] Barrero, P.R., Benavides, M.A., León, B.M., Barrero, V.D. and Vargas, V.V. (2005) Mastitis Granulomatosa idiopática y mastitis de células plasmáticas. Experiencia de tres años. Revista Chilena de Obstetricia y Ginecología, 70, 323-327. https://doi.org/10.4067/S0717-75262005000500008

[4] Jiménez González, M., Melero López, A. and Sánchez Gabaldon, R. (2015) Mastitis granulomatosa. Clínica e Investigación en Ginecología y Obstetricia, 42, 141-144. https://doi.org/10.1016/j.gine.2014.02.001

[5] Sabaté, J.M., Clotet, M., Gómez, A., De Las Heras, P., Torrubia, S. and Salinas, T. (2005) Radiologic Evaluation of Uncommon Inflammatory and Reactive Breast Disorders. Radiographics, 25, 411-424. https://doi.org/10.1148/rg.252045077

[6] Pluguez-Turull, C.W., Nanyes, J.E., Quintero, C.J., et al. (2018) Idiopathic Granulomatous Mastitis: Manifestations at Multimodality Imaging and Pitfalls. Radiographics, 38, 330-356. https://doi.org/10.1148/rg.2018170095

[7] Hovanessian Larsen, L.J., Peyvandi, B., Klipfel, N., Grant, E. and Iyengar, G. (2009) Granulomatous Lobular Mastitis: Imaging, Diagnosis, and Treatment. American Journal of Roentgenology, 193, 574-581. https://doi.org/10.2214/AJR.08.1528

[8] Vargas-Hernández, V.M. (2014) Mastitis granulomatosa idiopática. Revista del Hospital Juárez de México, 81, 174-181. https://www.medigraphic.com/pdfs/juarez/ju-2014/ju143g.pdf

[9] Mathew, T.V., Alexander, S.A., Bindal, P. and Vredenburgh, J. (2020) Idiopathic Granulomatous Mastitis-A Mystery Yet to Be Unraveled: A Case Series and Review of Literature. Cureus, 12, e6895. https://doi.org/10.7759/cureus.6895

[10] Manogna, P., Dev, B., Joseph, L.D. and Ramakrishnan, R. (2020) Idiopathic Granulomatous Mastitis-Our Experience. Egyptian Journal of Radiology and Nuclear Medicine, 51, Article No. 15. https://doi.org/10.1186/s43055-019-0126-4

[11] Medina, P.M., Navarro, O.M.C. and Rodríguez, G.M.Á. (2015) Mastitis granulomatosa idiopática, simuladora del cáncer de mama. Medicentro Electrónica, 19, 257-261.

[12] Guio Ávila, J.I., Cruz Rueda, Á.R. and Pérez Morón, J.E. (2016) Mastitis granulomatosa: Presentación clínica, imagenológica e histológica. Serie de casos. Repertorio de Medicina y Cirugía, 25, 235-240. https://doi.org/10.1016/j.reper.2016.11.003

[13] Aguilar, M. and Jiménez, R. (2003) Diagnóstico y tratamiento de la Mastitis GranulomatosaI diopática: A propósito de un caso. Revista de Senología y Patología 
Mamaria, 16, 140-142.

[14] Kok, K.Y.Y. and Telisinghe, P.U. (2010) Granulomatous Mastitis: Presentation, Treatment and Outcome in 43 Patients. The Surgeon, 8, 197-201.

https://doi.org/10.1016/j.surge.2010.02.002

[15] Gautier, N., Lalonde, L., Tran, D., et al. (2013) Chronic Granulomatous Mastitis: Imaging, Pathology and Management. European Journal of Radiology, 82, 165-175. https://doi.org/10.1016/j.ejrad.2012.11.010

[16] Garcia-Rodriguez, J.A. and Pattullo, A. (2013) Idiopathic Granulomatous Mastitis: A Mimicking Disease in a Pregnant Woman: A Case Report. BMC Research Notes, 6, Article No. 95. http://www.biomedcentral.com/1756-0500/6/95 https://doi.org/10.1186/1756-0500-6-95

[17] Sheybani, F., Naderi, H., Gharib, M., Sarvghad, M. and Mirfeizi, Z. (2016) Idiopathic Granulomatous Mastitis: Long-Discussed But Yet-to-Be-Known. Autoimmunity, 18, 236-239. https://doi.org/10.3109/08916934.2016.1138221

[18] Kessler, E. and Wolloch, Y. (1972) Granulomatous Mastitis: A Lesion Clinically Simulating Carcinoma. American Journal of Clinical Pathology, 1, 642-646.

https://doi.org/10.1093/ajcp/58.6.642 